\title{
Portrayal of Nurses in the Lyrics of the Music During World War I
}

\author{
Kelley H. Pattison ${ }^{1}$ \\ ${ }^{1}$ Bronson School of Nursing, Western Michigan University, Kalamazoo, Michigan, USA \\ Correspondence: Samuel P. Abraham, Associate Professor of Nursing, School of Nursing, Bethel University, \\ 1001 Bethel Circle, Mishawaka, Indiana, 46545, USA.
}

Received: August 24, 2021

Accepted: September 9, 2021

Online Published: September 11, 2021

doi:10.20849/ijsn.v6i3.924

URL: https://doi.org/10.20849/ijsn.v6i3.924

\begin{abstract}
Purpose: The study explores the description of nurses serving with the US Army and the American Red Cross during World War I as described in a collection of sheet music. The purpose was to identify themes within the lyrics which describe how the nurse was viewed at the time.

Background: Analyzing the description of nurses who served during World War I allows the present-day reader insight into how they were perceived by the soldiers they cared for and the public. The contrast between the two types of songs; those written from the point of view of the soldiers and songs written from the point of view of the public, provides an insight into the depiction of the nurses.

Method: Thematic analysis was used to review a collection of songs $(\mathrm{N}=29)$ for themes and examples of how nurses were described in the music lyrics of World War I music. Library of Congress music archives is the repository of the music reviewed.

Findings and conclusions: The song lyrics from the soldiers' point of view describe these women as beautiful, selfless angels, and much like their mothers back home. The lyrics from the public's point of view describe the nurses as one who does her part for the war effort, one who doesn't get enough praise, and a woman of courage. Many songs ask God to save the nurse. Looking back 100 years later, it is interesting to see how the nurse was a revered member of the US war effort during World War I.
\end{abstract}

Keywords: World War One, Red Cross Nurse, army nurse, nurses in music, song lyrics and nurses

\section{Introduction}

Patriotic songs have long been written during war to lift morale, increase feelings of honor and pride, strengthen resolve, and represent the nation (von Rhein, 2010). One hundred years ago, the songs were of support for the soldiers fighting in World War One. Looking back at the music composed during World War One discloses illustrations of patriotism and examples of how nurses were viewed.

The US Army Nurse Corps had 403 nurses in 1917. By the end of 1918, 21,480 nurses had enlisted (Armyheritage, 2021). The involvement of the United States in World War I is attributable to this huge increase in the Army Nurse Corps. Also contributing to the nursing response during World War I were 18,000 Red Cross nurses who also provided care to soldiers on the battlefields of France, on naval ships, and stateside where they cared for people afflicted by the 1918 influenza pandemic (Library of Congress, 2020).

\section{Purpose and Method}

The aim of this study was to identify how nurses were portrayed in the lyrics of the music of the World War One era. The titles and lyrics of 29 songs written from 1911 to 1919 were reviewed using thematic analysis to identify themes that illustrate the nurse's view. Ten themes were identified and are described below (see Figure $1)$. 


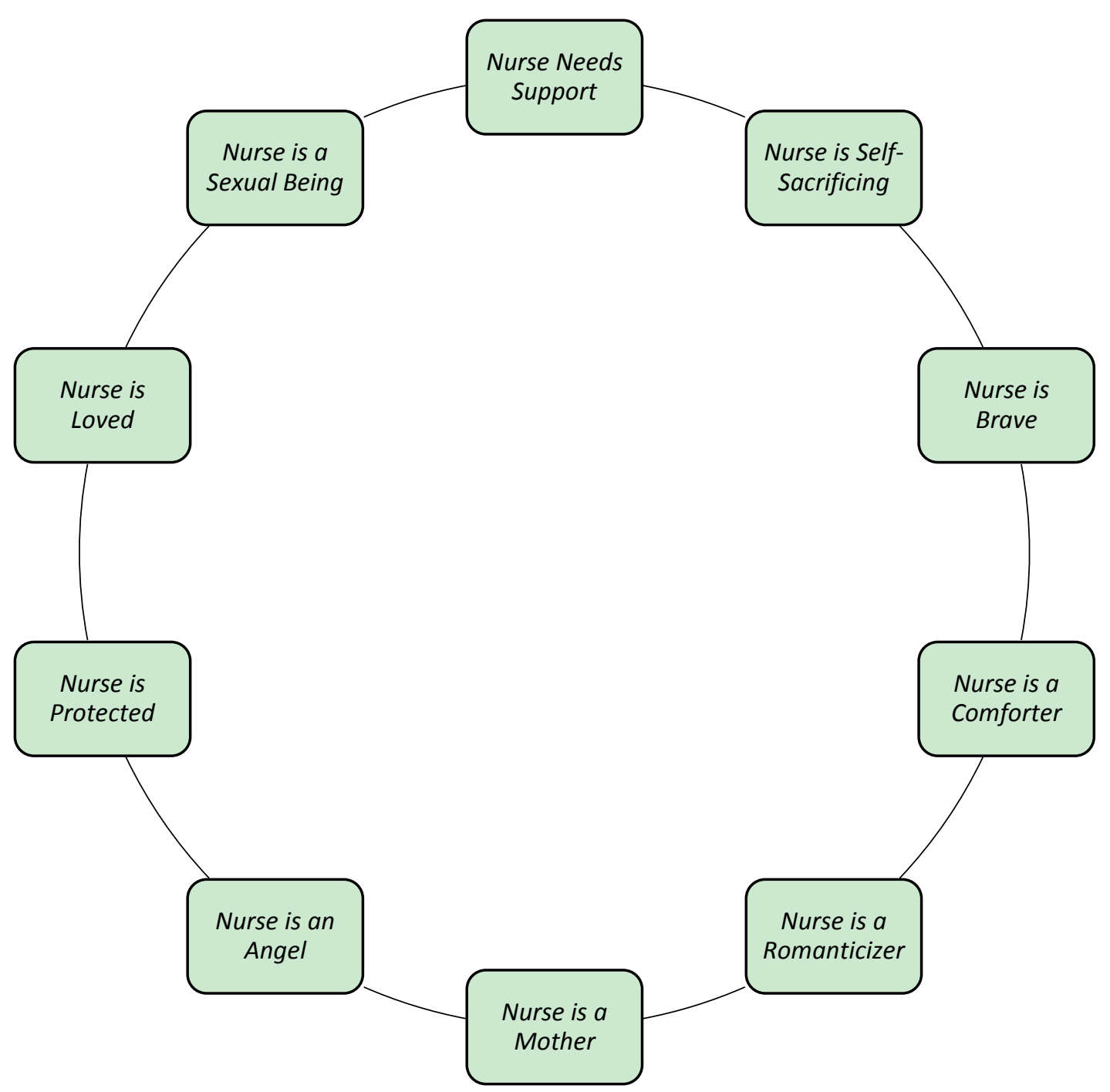

Figure 1. Themes emerging from the study portrayal of nurses in the lyrics of the music during World War I

\section{Description of Themes}

Of the 29 works reviewed, 18 had the words Red Cross Nurse in the title. These titles revealed much of the sentiments of the lyrics within the songs. Four of the titles contained the word little, for example, The Little Red Cross Nurse (McDonald, 1918), Dear Little Red Cross Nurse (Trubey, 1918), Little Red Cross Nurse (Richard \& Eshom, 1919), and My Little Red Cross Nurse (Van Horn \& Du Freer, 1919). The term little did not refer to her size but was a term of endearment.

\subsection{Nurse Is an Angel}

One common feature in the lyrics of these songs was the representation of the nurse as an angel, for example: "angels of kindness" (McDonald \& Redfield, 1911), "angel of mercy and light" (Trubey, 1918), "'Twas just an angel, just an angel from heaven" (Barnes, 1911), "She come as an angel from heaven sent from above on a mission of love. I needed an angel, and you were sent" (De Rose \& Roden, 1918). This is not surprising as nurses have often been referred to as angels of mercy.

\subsection{Nurse Is a Mother}

The nurse is often compared to the mother in the lyrics of these songs. "She reminds us of our mothers" (Power, 1918), "Got a mother's way of greeting like a mother used to do. With a smile just like our mother's and a heart that's just as true. She calls the soldiers her boys, their joys are her joys too" (Browne, 1917). "Next to mother come the Red Cross Nurses with their sympathetic and kindly ways" (Friedman \& Meyer, 1918). "But there is 
still another, to the soldiers she's a mother" (Orth \& Hicks, 1917). "After their soul has departed, like his mother's, their tears are shed" (McDonald \& Redfield, 1911). In these lyrics, not only is the nurse portrayed as a mother-like figure, but the soldier is a boy.

\subsection{Nurse Is a Romanticizer}

Nurses were often romanticized in the song lyrics. The song Remember the Nurse mentions "the tender touch of these angels" (Borradaile, 1918), while the words of Nurse O'Mine tell of "her touch entrancing- it thrills me so." (Barnes, 1911). Her tender hand and touch are also mentioned in Angels of the cross of Red (McDonald \& Redfield, 1911) and The Red Cross Nurse (Friedman \& Meyer, 1918). The nurse's tender eyes are mentioned in Nurse O'Mine. (Barnes, 1911). The image of the nurse is compared to sunshine, "Something just like sunshine when she passes their way." (Power, 1918) and "Her smile is like sunshine after the rain." (McDonald, 1918).

\subsection{Nurse Is a Comforter}

The nurse is seen as easing the pain and bringing aid to the soldiers. "Oh, what a blessing and comfort she is, to the soldiers far over the sea" (Browne \& Bates, 1911). "Your wounds I will bandage my brave soldier man. I'll try to soothe them and do what I can" (Larson, 1918). "Watching and caring for our boys." (Rainbow, 1918). In these lyrics, the nurse is portrayed in the traditional role of comforter and healer.

\subsection{Nurse Is Brave}

The nurses were also depicted as brave and doing their part for the war effort. Examples are "she serves the flag in a noble way" (Valentine, 1918). "She does her part unsung in rhyme or verse" (McDonald, 1918), "a cause just as true as the soldiers" (Moon \& Babb, 1917), and "doing her part for the USA." (Browne, 1917). The bravery of the nurses is also portrayed. "They're as brave as our stalwart soldiers." "She took a chance, and she's now in France" (Carlson \& Peterson, 1918). "You will find her on the battlefield, serving with fortitude sublime" (Seacrist, 1911).

\subsection{Nurse Is Self-Sacrificing}

These women often left their families to serve. This sacrifice is also depicted in the song lyrics. "There's a daughter gone to help the wounded. To nurse our boys across the sea" (Browne \& Baldwin, 1911). "A daughter too for her nation first; will do her part to help you as a Red Cross Nurse" (Piron \& Perrault, 1917). "She gave up both home and friends. She is doing her duty in France" (Van Moopes \& Petrullo, 1918).

\subsection{Nurse Needs Support}

Honoring and supporting the nurses is also revealed in the lyrics. "Our hearts are warm for the uniform of the Red Cross nurse" (Quaw, 1917). "Help them trust and strive. God save each one," are lyrics from A Song for Soldiers and Nurses (Rodfer, 1918). "While we cheer the boys in khaki, as we praise the boys in blue, there's another band of helpers we should honor too" (Trubey, 1918). "Our hats off to her, boys, don't forget the Red Cross nurse. She's American through and through" (Moon \& Babb, 1917).

\subsection{Nurse Is a Sexual Being}

Song titles and lyrics also portrayed the nurse as a sexual being. "I'd gladly be a wounded soldier if you will be my Red Cross nurse" is one example. The lyrics of this song state, "the wounds suffered would be a blessing if you would do the dressing" (Taverna, 1918).

The song Naughty Little Red Cross nurse asks the nurse to "just load your gun with kisses and shoot at me all day. Entrench yourself right in my arms, I'll surrender to your loving charms. There's no fun in fighting, you know that love comes first" (Friend, 1911).

Good-night Nurse is described as a comic song. With such lyrics as, "the nurse makes the soldier forget about his ills, they made love when she brought him pills, come here my cutie, and he left his wife for the nurse" (Walker \& Gray, 1912).

\subsection{Nurse Is Loved}

Love for the nurse is a recurrent theme in many of the song lyrics. "Every soldier boy loves the little Red Cross Nurse" (McDonald, 1918). The song, Remember the Nurse mentions that she is "adored like she is divine" (Borradaile, 1918). "We'll love you more each day," (Carlson \& Peterson, 1918), "we love and revere you," (Trubey, 1918), "everyone loves them," (McDonald, 1918), and "we are all in love with you" (Richard \& Eshon, 1919) are some examples from other songs of the time. This love of the soldier for the nurse is further represented in the line "We've longed to love her so" (Brennan, Caddigan, \& Jones, 1919). The forlorn soldier 
expresses his love for the nurse in the lyrics, "She would only read my temperature, she would not read my heart" (Van Horn \& Du Frerre, 1919).

\subsection{Nurse Is Protected}

Lastly, the soldier's point of view as a defender of the nurse is mentioned in the songs. "None would ever offend her," For her, all would die" (Borradaile, 1918), "We fight for you, we'd die for you" (McDonald, 1918) are lyrics of Little Red Cross Nurse and Remember the Nurse.

\section{Conclusion}

Looking back at the music of 100 years ago finds the nurse represented as a source of comfort, love, bravery, and patriotism. Immortalizing these women in song certainly did not make them the unsung heroes of World War I, but rather just the opposite; they were women who served bravely and of whom songs were written and sung.

\section{References}

Armyheritage.org. Army Nurse Corps: More than 100 years of service to our nation. Retrieved August 1, 2021, from https://www.armyheritage.org/soldier-stories-information/army-nurses-corps-more-than-100-years-of-servi ce-to-our-nation/

Barnes, H. (1911). Nurse O'Mine [Sheet music].

Borradaile, J. W. (1918). Remember the Nurse [Sheet music].

Brennan, J. A., Caddigan, J., \& Jones, S. (1919). The rose of "No Man's Land" [Sheet music]. Leo Feist.

Browne, R. A. (1917). She's just like a mother in France [Sheet music].

Browne, R. A., \& Baldwin, S. A. (1911). Mother's only girl gone to nurse the Yanks over there [Sheet music].

Browne, R. A., \& Bates, E. E. (1911). May God bless the Red Cross nurse today! [Sheet music].

Carlson, B. M., \& Peterson, M. M. (1918). Give a little credit to our Red Cross nurse [Sheet music].

Cassel, I. M. (1918). Hip! Hip! Hurrah for our Red Cross nurses [Sheet music].

De Rose, P., \& Roden, R. F. (1918). I never believed in angels until I met you girl of the cross [Sheet music]. F. B. Haviland.

Friedman, L., \& Meyer, J. A. (1918). The Red Cross nurses [Sheet music]. North American Music Company.

Friend, C. (1911). Naughty little Red Cross nurse [Sheet music].

Larson, M. E. (1918). The little patriot [Sheet music].

Library of Congress. American Women Health and Medicine: Red Cross and World War One. Retrieved May 1, 2020, from https://memory.loc.gov/ammem/awhhtml/awmss5/red_cross.html

McDonald, J. D., \& Redfield, W. M. (1911). Angels of the cross of red [Sheet music].

McDonald, J. H. (1918). The little Red Cross nurse [Sheet music]. Music Publishing Company.

Moon, N., \& Babb, L. W. (1917). She is just a girl that's serving Uncle Sam [Sheet music]. The Willis Music Company.

Orth, L., \& Hicks, C. K. (1917). Don't forget the Red Cross nurse [Sheet music]. Orth \& Coleman.

Piron, A. J., \& Perrault, S. J. (1917). America, they are both for you [Sheet music]. Williams \& Piron Music Publishing Company.

Power, C. (1918). There's a cross on the arm of the girl I love [Sheet music]. Livingstone Publishing Company.

Quaw, G. (1917). Under the banner of the Red Cross nurse [Sheet music]. National Publishing Company.

Rainbow, L. (1918). The greatest mother of them all [Sheet music]. Jerome H. Remick and Company.

Richard, A. L., \& Eshom, C. (1919). Little Red Cross nurse [Sheet music]. Legters Music Company.

Rodefer, D. (1918). A song for our soldiers and nurses [Sheet music].

Seachrist, J. (1911). The greatest mother in the world [Sheet music].

Taverna, R. (1918). I'd gladly be a wounded soldier if you will be my Red Cross nurse. [Sheet music]. George J. Jetter.

Trubey, A. (1918). Dear little Red Cross nurse [Sheet music]. 
Valentini, V. (1918). The American Red Cross nurse [Sheet music].

Van Horn, C. D., \& Du Freer, H. (1919). My little Red Cross nurse [Sheet music]. National Literacy and Publishers Service Bureau.

Van Moopes, M., \& Petrullo, R. J. (1918). She's an angel of the battlefield [Sheet music].

von Rhein, J. (2010, July 3). What Makes a Song Patriotic? Chicago Tribune. Retrieved from https://www.chicagotribune.com/entertainment/ct-xpm-2010-07-03-ct-ae-0704-music-patriotic-20100702-st ory.html

Walker, R., \& Gray, T. (1912). Good-night Nurse [Sheet music]. Jerome H. Remick and Company.

\section{Copyrights}

Copyright for this article is retained by the author(s), with first publication rights granted to the journal.

This is an open-access article distributed under the terms and conditions of the Creative Commons Attribution license (http://creativecommons.org/licenses/by/4.0/). 